\title{
UK scientists should take care
}

BRITISH scientists thinking of participating in Strategic Defense Initiative (SDI) research might do well to consider their legal position carefully. An incident in the United States in which basic research results were suddenly classified and what has recently become known about British Ministry of Defence (MoD) guidelines suggest that scientists may find it hard to protect their rights of free publication.

The terms of British involvement in SDI are enshrined in a memorandum of understanding between the British and United States governments. A research contract is placed by the SDI Organization (SDIO) in Washington, an office separate from the Pentagon, in one of five classified, military Project Areas, or in the $\$ 100$ million Innovative Science and Technology (IST) programme for basic science.

Exactly what regulations cover the latter programme are unclear. The SDI Participation Office in the MoD promises scientists the right to publish work that is also receiving SDI funding, with the provision that a copy of the paper of presentation is delivered to it and SDIO in Washington before publication.

Fundamental research will thus be free, as has often been claimed by the university liaison officer of the Ministry of Defence SDI office, George Gallagher Daggitt. But will this always be true? In response to a letter from Paul Labbett ( 8 April 1986), research contracts officer at Imperial College, London, Daggitt wrote: "It is however conceivable that exceptions to this rule could arise if there is the likelihood of disclosing operational capabilities and performance characteristics of developing military systems. In this case the contract for the work will clearly stipulate that responsibility for the release of information lies with the sponsoring office" (that is, SDIO in Washington).

The case of a US high-energy physicist. Dr Andrew Sessler, shows that successtul SDI research can easily be classified. His team's work on the free electron laser was guaranteed open for publication until he showed how gigawatt power outputs were possible in March 1985. SDIO immediately classified the entire experiment and the results. The work, largely paid for by the Department of Energy, was part of the civil fusion reactor programme. But as Sessler took a small grant from SDIO it became the sponsor. The work was classified top secret (Sessler and his staff were threatened with expulsion and jail if they released details) for 13 months until April this year, when the results alone were de-classified. The experimental details are still classified.

SDIO is free to classify what it sees fit. The memorandum can offer no guaran- tees that fundamental science will be open for publication. MoD Guidelines say a review procedure is available "so that appropriate representations can be made". But SDIO in Washington has the final say. A significant number of British scientists have applied for funding under IST: there are 36 individual proposals, and 2 consortia.

The memorandum embodies the principle that there will be no guaranteed work although the figure of $\$ 1,500$ million was floated early on. Days before the memorandum of understanding was signed, the British draft contained a schedule of work in three categories: commercial work from research into manufacture worth $\$ 1,000$ million, government contracts for research worth $\$ 250$ million and university research up to $\$ 250$ million. How much will British companies and individual researchers actually gain in SDI? From $\$ 50$ to $\$ 100$ million in total, estimates MoD.

MoD can identify five commercial contracts worth a total of $\$ 1$ million. Another 12 contracts are in negotiation, each worth around $\$ 2$ million. The first round of IST proposals might bring another $\$ 10$ million. Government-to-government business could rise from the present $\$ 15$ million to $\$ 50$ million.

The government agreed a special research contract for the work in which it is the principal or subcontractor. The Letter of Offer and Acceptance negoti- ated to cover the first two contracts, "written according to patent law" according to the SDI Office in the MoD, acts as a standard contract for SDI research and is said to safeguard the rights of ownership of technology. The letter is secret and applies only to government work. Yet it is said to embody the best definition of intellectual property right, and to safeguard technology produced in SDI for the researcher concerned.

Why should it be secret? And why cannot other researchers use the definition of intellectual property right? MoD says it is for private individuals and companies to get the best deal they can for themselves even though the memorandum of understanding was intended to act as an umbrella agreement for all participants. The Americans insisted on this arrangement.

Government work can only be research, not manufacture, and must stay within the terms of the 1972 Anti-Ballistic Missile (ABM) Treaty according to the memorandum of understanding.

A joint MoD/Foreign Office Arms Control Unit has a veto on government research proposals that threaten to stray beyond other treaty obligations. If a British company were to design, prototype, test or build a component of SDI. however, it is unclear in the memorandum whether or not such proposals could be vetoed.

The right to own technology originating in a research contract funded either by SDIO (as basic science), or in a subcontract with a US company (on project work), is not defined in the memorandum. This is thought to have contributed to the

\section{UK star wars consortium launched}

A consortium of eleven UK defence contractors has bid jointly for the first Strategic Defense Initiative (SDI) contract worth \$9.9 million, the European Architecture Study, let to the Ministry of Defence by the Strategic Defense Initiative Organization (SDIO) in Washington, DC.

Ian Sutherland, a director of Marconi, said that this "team" will share out research work if it secures the entire study and would work together as "UK Ltd" on the SDI contracts that follow on. These could be worth tens of millions of dollars.

The group includes defence contractors GEC-Marconi, British Aerospace, Barr \& Stroud and Shorts, electronics companies Thorn EMI, Racal and Ferranti, the Royal Ordnance Factory, and computer software houses CAP Scientific, Scicon and Software Sciences.

The architecture study will consider how an SDI system could operate in Europe. Four subcontracts will be awarded, probably in September, in computer systems, weapons, battle management and command, control and communication.
Few contracts have yet been awarded to British companies. Sutherland said Marconi has sold " $£ 4$ million worth of hardware", including exotic electronic components such as thyratrons (which switch very high currents quickly) and silicon-on-sapphire semiconductors (which are relatively unaffected by radiation). In addition, Marconi Projects has two research subcontracts worth under $\$ \mathbf{2 5 0 , 0 0 0}$.

Up to 12 other proposals are in the pipeline, including those for electromagnetic guns, battle management, lethality and target hardening, very high speed integrated circuits, high-energy lasers, advanced sensors and particle beams.

SDIO in Washington has also requested access to the Ministry of Defence's results from the Teal Ruby experiment which considered strategic defence from short-range and mid-range missile attack. But the Australian government, which collaborated in the experiment, is set against SDI participation and Australian permission is necessary before results can be released.

Paul Walton 
low take-up of work by companies. Background research, that is existing company data on intellectual property rights defined by patent or copyright, can be protected. But foreground research, that produced during a funded contract, is not protected by the memorandum.

As things stand, a US prime contractor would be legally entitled (under US law) to patent foreground research, denying use to the originator for 17 years. This patent defines the owner as the body which pays, not the individual or organization which completes the research.

A further problem for British researchers is that the memorandum does not waive those items of US law, in particular the Export Administration Act, that make

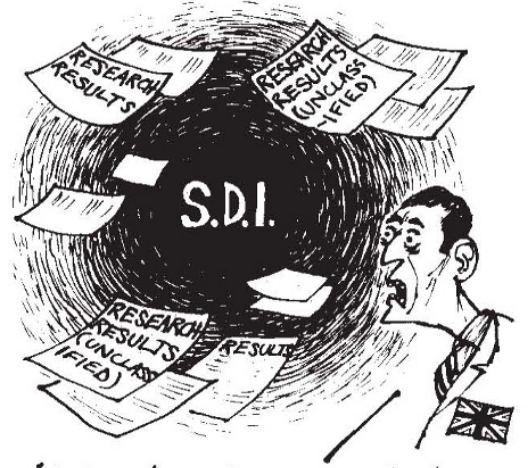

At least we've proved the existence of Black Holes...

it difficult for items of technology or technical data in the form of proposals or descriptions to be passed freely between Britain and the United States.

Technology transfer law still applies to SDI work. "Both Governments will make every effort to process within 30 days requests for export licences for technical data packages or other controlled information for direct bidding", according to the memorandum. In practice, clearance can take several months, by which time an SDI contract will have been let. Visits to secure sites, to closed conferences, or to discuss classified information with a partner in the United States requires prior clearance, and full vetting, of any person by the US authorities. It is likely that positive vetting will be carried out by US embassy staff in the United Kingdom. Most British citizens will be required to sign the Official Secrets Act.

The memorandum is "secret in perpituity", or top secret. A full debate on British participation has been requested by Labour MP Tam Dalyell but denied on the basis that the United Kingdom has negotiated a good deal which the United States does not wish other allies to know of in detail. All the UK opposition parties, Labour, Liberal and Social Democrats, have pledged that they will do away with the memorandum and pull out of SDI.

Paul Walton

\section{US space}

\section{Shuttle faces more delay}

Washington

THE US National Aeronautics and Space Administration (NASA) announced last week that shuttle flights will not now resume before 1988, despite earlier estimates that the shuttle might fly again as soon as next summer. Although disappointing, the delay, say NASA officials, is necessary to complete a review of the design and testing of the solid rocket motors (SRMs) responsible for last January's shuttle accident.

In a report requested by President Reagan, NASA spelled out its plans for implementing the recommendation of the Rogers Commission on the accident (see Nature 321, 637; 1986). NASA hopes to redesign the SRMs so that existing hardware can be used, but there are alternatives using completely new hardware in case that plan is frustrated. At NASA's request, the National Research Council (NRC) has established an independent oversight group, chaired by H. Guyford Stever, to superintend the redesign.

Other hardware modifications recommended by the Rogers Commission included improvements in the tyre, brake and nose-wheel steering systems. NASA says that some of those improvements were under way at the time of the accident, and that the other modifications are in hand. Until the improvements are judged a success, the shuttle will continue to land at Edwards Air Force Base in California, where there is a longer landing strip. Ultimately NASA hopes to land shuttles at the Kennedy Space Center in Florida where they are launched. NASA also plans a thorough review of all critical safety items on the shuttle, and a second NRC oversight panel is being formed to watch over that process as well. Not sur-

prisingly, safety issues are uppermost in the minds of most NASA officials. Waivers allowing marginal parts to be used in launches will be few and far between, says one NASA official.

NASA has also begun two separate reviews of its much criticized management practices. One will look at the shuttle programme, the other at NASA as a whole. Many at NASA involved in the shuttle have either left the agency or been transferred since the accident. The latest casualty is Lawrence Mulloy, director of the SRM programme at the beginning of the year, who resigned last week after having been transferred from that programme.

NASA has yet to make a final decision about crew escape systems, but preliminary conclusions suggest that no approach will provide a safe escape route under all conditions. But further attention is to be paid to procedures for aborting launches, including one scheme for transatlantic escape.

The Rogers Commission pointed out that total reliance on the shuttle for launches had put heavy pressure on NASA to increase its launch rate. NASA hopes that the pressure will be partly reduced by the new policies it has adopted on the choice of cargo for the shuttle bay, but it is also now backing the claims of other agencies that there should be a mixed fleet of launch vehicles, including expendable rockets. Responding to a request from Congress, NASA has asked NRC to form a third panel that will evaluate launch rates and the balance between manned and unmanned launch systems. Edward David, president of Exxon Research and Engineering Company, will chair this committee.

Joseph Palca

\section{Now it's save French science!}

French scientists appear to be getting more and more like their British colleagues - absolutely desperate. But in one way the French are going further. Discovering that appeals to their own government over recent cuts have failed (no doubt in part because, as it is said, the new science minister is uninterested in politics), they have gone to the lengths of producing an international petition: "Save CNRS" (the principal French research council).

"We the undersigned members of the international scientific community", the petition reads, "wish to express our grave concern regarding the policy followed by the French government. The policy has already resulted in: budget cuts (more than FF 4,000 million - $\mathbf{4 4 0 0}$ million); 25 per cent reductions in new posts for 1986; a decision to cut the number of scientists employed by government in 1987; the smallest ratio of research spending to gross national product in the West; and the suppression of the CNRS Comité National." The Comité is a decision-making body whose loss brings to a standstill the whole administrative machinery of the CNRS including the setting up of new posts and grants.

The petition calls for the French government to reinstate the Comité National, and reverse the new downward trend in jobs and cash for French science. What it fails to do, however, is to give an address to which to send the completed petition. But interested readers could always try the French Prime Minister, Jacques Chirac, at the Matignon...
Robert Walgate 